\title{
A Pre-experimental Study to Assess the Effectiveness of Structured Teaching Programme on Knowledge Regarding Substances Abuse among Boys at Selected Senior Secondary Schools in Jalandhar, Punjab state of India
}

\author{
Jagwinder Singh ${ }^{1}$, Rajratan Gupta ${ }^{2 *}$, Reema J. Andrade ${ }^{3}$ \\ ${ }^{1}$ Vocation trainer coordinator, Vidyanta skills institute Pvt. Ltd, Gurgaon, India \\ ${ }^{2}$ Assistant Professor, Department of Psychiatric Nursing, Nursing College, AlIMS Bhopal, India \\ ${ }^{3}$ Registered Nurse, Northern Devon District Hospital, Barnstaple, United Kingdom
}

\begin{abstract}
Background: Substances abuse is dangerous not only for health but also in the view of economic and social values. The habit of substance abuse becomes the cause of purposeless waste of money and affects health. This study was conducted to assess the effectiveness of a structured teaching program on knowledge regarding substances abuse among boys at selected senior secondary schools.

Methodology: A pre-experimental pretest-posttest is used. The setting is at senior secondary schools Jalandhar. The sample includes 60 boys selected by a convenient sampling technique. The tool consisted: Part 1 demographic variables and part 2 structured knowledge questionnaire. The reliability of the tool was established by using the split-half method.

Results: The study's findings show that the mean score, median score and SD in the pre-test were 12.78, 12.5 and 2.92 , respectively, whereas the mean score, median score, and SD in post-test were $22.58,23$ and 2.02, respectively. The calculated ' $t$ ' value was found to be 19.2 while the tabulated value of the ' $t$ ' at 0.05 level of significance is 1.645 , which is lesser than the calculated ' $t$ ' value. It was safely assumed that STP had a definite impact on raising students' knowledge of substances abuse.

Keywords: Effectiveness, Substances abuse, Boys, Senior secondary schools.

Int J Eth Trauma Victimology (2021). DOI: 10.18099/ijetv.v7i02.4
\end{abstract}

\section{INTRODUCTION}

A dolescence is signaled by puberty rights, usually in tests of strength and courage. The completion entitles the individual to be recognized as a young adult. ${ }^{2}$

Man's internal thirst for new and more enriching experiences has driven him beyond the routine and mundane pleasure of every day to search for and reliance on substances. Those are even momentarily affording him relief from monotony and uniqueness of perception. These experiences are satiating not only in themselves but also because then. They make the individual stand apart from his fellow beings. Immutable research has been conducted and a great deal more has been written about the nature and consequences of these mind-changing drugs/substances, yet they remain an enigma. They have been hailed as of enormous social, medical, and religious value and the most destructive, pathogenic, and misleading discovery of all times. ${ }^{3}$

In India, the last two decades have been a period of rapid increase in the percentage of drug and alcohol abusers. Alcohol is getting a social sensation over a wider stratum of society. There has been a marked increase in the use of heroin (popularly known as smack and brown sugar) in our country in the last few years. The affected group has also changed. Earlier, it was usually seen among the elites, upper-middle-class, and student communities. But today, the class, age, and education are no

\footnotetext{
CIJETV. All rights reserved
}

Corresponding Author: Rajratan Gupta, e-mail: rajratan. nursing@aiimsbhopal.edu.in

How to cite this article: Singh, R., Gupta, R., Andrade, R.J. APre-experimental Study to Assess the Effectiveness of Structured Teaching Programme on Knowledge Regarding Substances Abuse among Boys at Selected Senior Secondary Schools in Jalandhar, Punjab state of India. Int J Eth Trauma Victimology. 2021;7(2):16-22.

Source of support: Nil

Conflict of interest: None

Received:25/11/2021;

Accepted:06/12/2021;

Received in revised form: 03/12/2021; Published:20/02/2022

bar for drug and alcohol abuse. A new risk group has emerged: youth educated and illiterate, employed and unemployed, rural and urban industrial workers, labor class and people on tour. ${ }^{5}$

Some teens face personal challenges that compound their risk of substance use and addiction. These include: a genetic predisposition toward developing an addiction or a family history of substance use disorders, adverse childhood events, such as abuse, neglect or other trauma, co-occurring mental health problems, peer victimization or bullying. ${ }^{5}$

A range of effective treatments for adolescent substance use disorders has been developed, including cognitive-behavioral techniques and motivational enhancement therapies. Programs 
more likely to be effective are built on strong evidence, are family-oriented, developmentally appropriate, and delivered by qualified health care professionals. Yet programs to treat teens with substance use disorders are few and far between and, of the programs that do exist, few are tailored to the unique needs of teens. Access to treatment is constrained further by cost, limited insurance coverage and an inadequate referral stream from health care providers who are not well informed of appropriate and effective treatment options ${ }^{8}$

\section{Materials and Methods}

\section{Study Design \& Sample Size}

A pre-experimental research approach is used in the present study. One group pretest-posttest design (no control group or randomization) is used to find the effectiveness of structured teaching programs on knowledge regarding substance abuse among boys at selected senior secondary schools Jalandhar, Punjab. The data collection period extended in February 2014 as per the convenience of the adolescents. the study consists of 60 samples, between the age of 15-18 years were participated. A pretest was conducted and, STP was given to students on the same day, and a post-test was taken from same samples on the $7^{\text {th }}$ day.

\section{Ethical Consideration}

Institutional Ethical Permission was obtained( letter no.: BINT/ PO/IEC/029 DT 10/05/2013). Data was collected after getting formal permission from the concerned authorities.

\section{Data Collection Measures}

Convenient sampling technique (Non-Probability Sampling Technique) was used to collect the sample validated by experts and found reliable. Data collection tools are the procedures or instruments used by the researcher to observe or measure key variables in the research problem. It is prepared in Section A- It consists of demographic data with 13 items (Age, Religion, Education grade, Education of father, Occupation of father, education of mother, Occupation of mother, Types of family, Monthly income of a family, Family history of substances abuse, Source of information. Section B- consists of a self-structured multiple-choice questionnaire to assess the knowledge of adolescence regarding substances abuse. It contains 30 multiple-choice questions. Data was collected by self-administration of knowledge assessment questionnaire by study subjects. Each correct answer was given a score of "one" and the wrong answer was "zero". The total score given was 30 . The score was interpreted as, Poor $=0-8$, Satisfactory $=$ $9-15$, Good $=16-24$, Excellent $=25-30$.

\section{Statistical Analysis}

Descriptive and Inferential statistics were used to analyze data as per the objectives and hypothesis. In the descriptive analysis, calculations were done by using frequency and percentage. mean, median and SD \& for inferential statistics chi-square test was used to find out the association between pre and posttest knowledge score regarding substances abuse and selected demographic variables
Table 1 : Frequency and Percentage Distribution of Demographic variables of boys $(n=60)$

\begin{tabular}{|c|c|c|c|}
\hline S. No. & Demographic Data & $F$ & $\%$ \\
\hline 1 & $\begin{array}{l}\text { Age } \\
\text { a) } 15-16 \\
\text { b) } 16-17 \\
\text { c) } 17-18 \\
\text { d) } 18 \text { and above }\end{array}$ & $\begin{array}{l}21 \\
16 \\
12 \\
11\end{array}$ & $\begin{array}{l}35 \% \\
26.67 \% \\
20 \% \\
18.33 \%\end{array}$ \\
\hline 2 & $\begin{array}{l}\text { Religion } \\
\text { Sikh } \\
\text { Hindu } \\
\text { Muslim } \\
\text { Christian }\end{array}$ & $\begin{array}{l}15 \\
40 \\
4 \\
1\end{array}$ & $\begin{array}{l}25 \% \\
66.67 \% \\
6.67 \% \\
1.66 \%\end{array}$ \\
\hline 3 & $\begin{array}{l}\text { Education grade } \\
11^{\text {th }} \\
12^{\text {th }}\end{array}$ & $\begin{array}{l}29 \\
31\end{array}$ & $\begin{array}{l}48.33 \% \\
51.67 \%\end{array}$ \\
\hline 4 & $\begin{array}{l}\text { Education of father } \\
\text { Illiterate } \\
\text { Upto primary level } \\
\text { Upto secondary level } \\
\text { Graduation } \\
\text { Post graduation and above }\end{array}$ & $\begin{array}{l}7 \\
23 \\
23 \\
5 \\
2\end{array}$ & $\begin{array}{l}11.67 \% \\
38.33 \% \\
38.33 \% \\
8.33 \% \\
3.33 \%\end{array}$ \\
\hline 5. & $\begin{array}{l}\text { Occupation of father } \\
\text { Farmer } \\
\text { Businessman } \\
\text { Dailywages } \\
\text { Government employee } \\
\text { Unemployed } \\
\text { Private employee }\end{array}$ & $\begin{array}{l}3 \\
8 \\
19 \\
8 \\
2 \\
20\end{array}$ & $\begin{array}{l}5 \% \\
13.33 \% \\
31.67 \% \\
13.33 \% \\
3.33 \% \\
33.33\end{array}$ \\
\hline 6. & $\begin{array}{l}\text { Education of mother. } \\
\text { Illiterate } \\
\text { Up to primary level } \\
\text { Up to secondary level } \\
\text { Graduation } \\
\text { Post graduation and above }\end{array}$ & $\begin{array}{l}13 \\
19 \\
24 \\
2 \\
2\end{array}$ & $\begin{array}{l}21.67 \% \\
31.67 \% \\
40 \% \\
3.33 \% \\
3.33 \%\end{array}$ \\
\hline 7. & $\begin{array}{l}\text { Occupation of mother } \\
\text { Housewife } \\
\text { Dailywages } \\
\text { Government employee } \\
\text { Private worker } \\
\text { Unemployed }\end{array}$ & $\begin{array}{l}48 \\
3 \\
5 \\
4 \\
0\end{array}$ & $\begin{array}{l}80 \% \\
5 \% \\
8.33 \% \\
6.67 \% \\
0 \%\end{array}$ \\
\hline 8. & $\begin{array}{l}\text { Types of family } \\
\text { Nuclear } \\
\text { Joint } \\
\text { Extended }\end{array}$ & $\begin{array}{l}31 \\
14 \\
15\end{array}$ & $\begin{array}{l}51.67 \% \\
23.33 \% \\
25 \%\end{array}$ \\
\hline 9. & $\begin{array}{l}\text { Monthly income of the family in } \\
\text { rupees. } \\
\text { a) } 5,000-10,000 \\
\text { b) } 10,000-15,000 \\
\text { c) } 15,000-20,000 \\
\text { d) } 20,000 \text { and above }\end{array}$ & $\begin{array}{l}40 \\
13 \\
4 \\
3\end{array}$ & $\begin{array}{l}66.67 \% \\
21.67 \% \\
6.67 \% \\
5 \%\end{array}$ \\
\hline 10. & $\begin{array}{l}\text { Family history of substances } \\
\text { abuse } \\
\text { At regularinterval } \\
\text { Occasionally } \\
\text { Daily } \\
\text { Never }\end{array}$ & $\begin{array}{l}15 \\
13 \\
12 \\
20\end{array}$ & $\begin{array}{l}25 \% \\
21.67 \% \\
20 \% \\
33.33 \%\end{array}$ \\
\hline 11. & $\begin{array}{l}\text { Common substances abused. } \\
\text { Alcohol } \\
\text { Tobacco }\end{array}$ & $\begin{array}{l}20 \\
5\end{array}$ & $\begin{array}{l}33.33 \% \\
8.33 \%\end{array}$ \\
\hline
\end{tabular}


The Effectiveness of Structured Teaching Programme on Knowledge Regarding Substances Abuse

\begin{tabular}{|c|c|c|c|}
\hline & Cigarette & 10 & $16.67 \%$ \\
\hline & Opium & 4 & $6.67 \%$ \\
\hline & Cannabis & 1 & $1.67 \%$ \\
\hline & None & 20 & $33.33 \%$ \\
\hline \multirow[t]{7}{*}{12.} & $\begin{array}{l}\text { Family member abusing } \\
\text { substances. }\end{array}$ & & \\
\hline & Mother & 1 & $1.67 \%$ \\
\hline & Father & 30 & $50 \%$ \\
\hline & Sister & 0 & $0 \%$ \\
\hline & Brother & 5 & $8.33 \%$ \\
\hline & Self & 4 & $6.67 \%$ \\
\hline & No one & 20 & $33.33 \%$ \\
\hline \multirow[t]{5}{*}{13.} & $\begin{array}{l}\text { Source of information regarding } \\
\text { substances abuse }\end{array}$ & & \\
\hline & Healthpersonnel & 16 & $26.67 \%$ \\
\hline & Massmedia & 11 & $18.33 \%$ \\
\hline & Relatives/Friends/Familymembers & 24 & $40 \%$ \\
\hline & Books,literature & 9 & $15 \%$ \\
\hline
\end{tabular}

\section{RESUlTS}

Table 1 reveals about Demographic characteristics, that according to age majority $35 \%$ of boys were in the age of $15-16$ years. religion, most of the boys (66.67\%) were Hindus and 25\% were Sikhs and $8.33 \%$ related to other religions. According to education, $(51.67 \%)$ of boys was studying in the $12^{\text {th }}$ class. education of fathers mostly is educated at the primary level $(38.33 \%)$ and up to the secondary level(38.33\%). The father's occupation, $33.33 \%$ were private employees and $31.67 \%$ were working for daily wages. education of mother, the majority of student's mothers were educated up to secondary level ( $40 \%$ ) and up to primary level (31.67\%). Whereas occupation of mother, most women (80\%) were housewives. participants type of family, the majority (51.67\%) of boys belonged to nuclear family. Their monthly family income, the majority (66.67\%) of boys had their monthly income below Rs.10000. The family history of substances abuse, $66.67 \%$ of boys said someone abused substances in the family mostly by father $(50 \%)$ or brother $(8.33 \%)$. According to common substances abused, the majority (33.33\%) of boys said alcohol is mostly abused in their family. The majority of the participant's sources of information regarding substances abuse, (40\%) of boys acquired information from relatives/friends, while $26.67 \%$ of adolescence acquired information from health personnel.

Table 2 explains students' frequency and percentage distribution according to pre-test knowledge scores regarding substance abuse. Maximum students (68.33\%) had a satisfactory level of knowledge and minimum (6.67\%) had poor knowledge while (21\%) had a good level of knowledge whereas none of the students had an excellent level of knowledge score.

Table 3 depicts students' frequency and percentage distribution according to post-test knowledge scores regarding substances abuse. Maximum students $(80 \%)$ had a good level of knowledge and (20\%) had an excellent level of knowledge. None of the students had satisfactory and poor knowledge scores.
Table 2 : Frequency and percentage distribution of pre-test knowledge score regarding substances abuse $(n=60)$

\begin{tabular}{llll}
\hline Level of knowledge & Score & $f$ & $\%$ \\
Poor (s25) Satisfactory (26-50\%) & $0-8$ & 4 & $6.67 \%$ \\
Good (51-75\%) & $9-15$ & 41 & $68.33 \%$ \\
Excellent (>75\%) & $16-24$ & 15 & $25 \%$ \\
& $25-30$ & 0 & $0 \%$ \\
\hline
\end{tabular}

Maximum Score $=30$, Minimum Score $=0$

Table 3: Frequency and percentage distribution of post-test knowledge score regarding substances abuse $(n=60)$

\begin{tabular}{llll}
\hline Level of knowledge & Score & $N$ & $\%$ \\
\hline Poor ( $\leq 25)$ Satisfactory (26-50\%) & $0-8$ & 0 & $0 \%$ \\
Good (51-75\%) & $9-15$ & 0 & $0 \%$ \\
Excellent (>75\%) & $16-24$ & 48 & $80 \%$ \\
& $25-30$ & 12 & $20 \%$ \\
\hline
\end{tabular}

Maximum Score $=30$, Minimum Score $=0$

Table 4: Comparison of pre and post-test mean knowledge score regarding structured teaching questionnaires on substances abuse $(n=60)$

\begin{tabular}{llc}
\hline & Pre-test & Post-test \\
\hline Mean & 12.78 & 22.58 \\
Median & 12.5 & 23 \\
SD & 2.92 & 2.02 \\
"'t' test $^{\text {M }}$ & & $19.2^{*}$ \\
\hline
\end{tabular}

Maximum Score $=30$, Minimum Score $=0$

Table 4 reveals that the mean score, median score and SD in the pre-test was $12.78,12.5$, and 2.92 , respectively, whereas the mean score, median score, and SD in post-test were 22.58, 23 , and 2.02 , respectively. The calculated " $t$ " value was found to be 19.2, while the tabulated value of the " $\mathrm{t}$ " at 0.05 level of significance is 1.645 , which is lesser than the calculated " $\mathrm{t}$ " value.

Hence null hypothesis is rejected, and the research hypothesis is accepted that is the post-test knowledge score regarding substances abuse was significantly higher than the pre-test knowledge score. It can be safely assumed that STP had a definite impact on raising students' knowledge.

Table 5 shows the association between pre-test knowledge scores regarding substances abuse with selected demographic variables.

The chi-square test is used to find the association between the pre-test knowledge score with the selected demographic variables. The tabulated chi-square value at 0.05 level of significance for $1 \mathrm{df}$ (degree of freedom) is 3.84. If the calculated chi-square value is greater than the tabulated value, then the null hypothesis will be rejected and will be concluded that there is a significant association between the pre-test knowledge score and the particular demographic variable.

It is seen that there is a significant association between the pre-test knowledge score and the religion of the students the calculated value is 11.87. the null hypothesis is rejected in this case, while there is no significant association between the pretest knowledge score and any other demographic variables. Thus 
Table 5 : Findings related to association between demographic variable and pre-test knowledge score $(n=60)$

\begin{tabular}{|c|c|c|c|c|c|}
\hline S. No. & Demographic variable & $\geq$ Median & $<$ Median & Chi-square value & Inference \\
\hline \multirow[t]{3}{*}{1.} & Age (in years) & & & \multirow{3}{*}{1.83} & \multirow{3}{*}{$\mathrm{N}$} \\
\hline & a. $15-17$ & 22 & 17 & & \\
\hline & b. $>17$ & 8 & 13 & & \\
\hline \multirow[t]{3}{*}{2.} & Religion & & & & \\
\hline & a. Hindu & 20 & 20 & \multirow{2}{*}{11.87} & \multirow{2}{*}{$S$} \\
\hline & b. Minorities & 19 & 1 & & \\
\hline \multirow[t]{3}{*}{3.} & Education grade & & & & \\
\hline & a. $11^{\text {th }}$ & 12 & 17 & \multirow{2}{*}{1.09} & \multirow{2}{*}{ NS } \\
\hline & b. $12^{\text {th }}$ & 17 & 14 & & \\
\hline \multirow[t]{4}{*}{4.} & Education of father & & & & \\
\hline & a. Up to primary level & 13 & 18 & \multirow{3}{*}{2.43} & \multirow{3}{*}{ NS } \\
\hline & & & & & \\
\hline & b. Secondary level to post graduate & 18 & 11 & & \\
\hline \multirow[t]{3}{*}{5.} & Occupation of father & & & & \\
\hline & a. Self employed. & 8 & 16 & \multirow{2}{*}{2.86} & \multirow{2}{*}{ NS } \\
\hline & b. Regular employment & 20 & 16 & & \\
\hline \multirow[t]{3}{*}{6.} & Education of mother & & & & \\
\hline & a. Up to primary level & 13 & 19 & \multirow{2}{*}{1.61} & \multirow{2}{*}{ NS } \\
\hline & b. Secondary to post graduation level & 17 & 11 & & \\
\hline \multirow[t]{3}{*}{7.} & Occupation of mother & & & & \\
\hline & a. Unemployed. & 21 & 26 & \multirow{2}{*}{3.38} & \multirow{2}{*}{ NS } \\
\hline & b. Employed & 9 & 3 & & \\
\hline \multirow[t]{3}{*}{8.} & Types of Family & & & & \\
\hline & a. Nuclear & 16 & 15 & \multirow{2}{*}{0.06} & \multirow{2}{*}{ NS } \\
\hline & b. Joint & 14 & 15 & & \\
\hline \multirow[t]{3}{*}{9.} & Monthly income of family (in rupees) & & & \multirow{3}{*}{1.7} & \multirow{3}{*}{ NS } \\
\hline & a. $5000-15000$ & 24 & 29 & & \\
\hline & b. 15000 and above & 5 & 2 & & \\
\hline \multirow[t]{3}{*}{10.} & Family history of substances abuse. & & & & \\
\hline & a. No & 13 & 7 & & \\
\hline & b. Yes & 17 & 23 & 0.13 & NS \\
\hline \multirow[t]{3}{*}{11.} & Source of information regarding substances abuse. & & & & \\
\hline & a. Health personal, relative and friends & 23 & 17 & 2.7 & NS \\
\hline & b. Mass media, books, literature & 7 & 13 & & \\
\hline
\end{tabular}

$\mathrm{S}=$ Significant, $\mathrm{NS}=$ Not significant

it is concluded that the null hypothesis is accepted in the other cases.

In Table 6, it is seen that the calculated chi-square value for an educational grade is 13.03. This value is significantly higher than the tabulated chi-square value at 0.05 level of significance which is 3.84 .

Thus, the null hypothesis is rejected and the research hypothesis is accepted and concluded that there is a significant association between the post-test knowledge score with educational grade. No association was found between any other variables and post-test knowledge score. Thus null hypothesis is accepted in all other cases.

\section{Discussion}

The findings of the study showed that maximum students $(68.33 \%)$ had an average level of knowledge and minimum (6.67\%) had below-average knowledge and 25\% had a good level of knowledge and the excellent level of knowledge $(0 \%)$. Thus, it was evident that the majority of students had an average level of knowledge regarding substances abuse. The mean score, median score and SD in the pre-test was 12.78 , 12.5 and 2.92 respectively.

This study was supported by Syed Masud Ahmed and AKM Masuel Rana"s descriptive study on general knowledge 


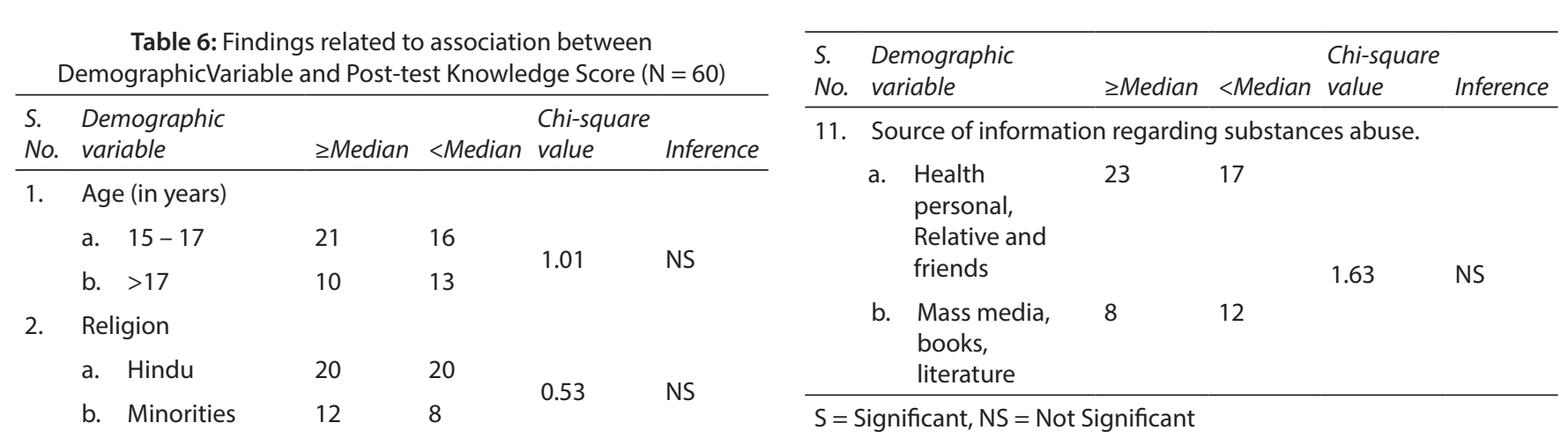

3. Education Grade

$\begin{array}{llllll}\text { a. } 11^{\text {th }} & 8 & 21 & & \\ \text { b. } 12^{\text {th }} & 23 & 8 & 13.03 & \mathrm{~S}\end{array}$

4. Education of father

\begin{tabular}{|c|c|c|c|}
\hline $\begin{array}{l}\text { a. Up to primary } \\
\text { level }\end{array}$ & 14 & 16 & \\
\hline $\begin{array}{l}\text { b. Secondary to } \\
\text { Post graduation } \\
\text { level }\end{array}$ & 16 & 14 & 0.27 \\
\hline
\end{tabular}

5. Occupation of father
a. Self employment
b. Regular $19 \quad 17$ employment

6. Education of mother
a. Up to primary $16 \quad 16$ level
b. Secondary to 16 Post graduation level.

7. Occupation of mother
a. Unemployed 23
b. Employed

8. Types of Family

$\begin{array}{lllll}\text { a. Nuclear } & 13 & 18 & 2.43 & \text { NS } \\ \text { b. Joint } & 18 & 11 & & \end{array}$

9. Monthly income of family (in rupees)
a. $5000-15000 \quad 26 \quad 27$
b. 15000 and 52 above

9. Monthly income of family (in rupees)
a. $5000-15000 \quad 26 \quad 27$
b. 15000 and 5 above

10. Family history of substances abuse.
a. No

$\begin{array}{ll}11 & 9 \\ 20 & 20\end{array}$

10. Family history of substances abuse.
a. No $11 \quad 9$
b. Yes
$20 \quad 20$
$2.7 \quad$ NS

on substances abuse among adolescent boys and girls in New Delhi, Mean knowledge score in the area related to narcotics was $42 \%$ and $39.9 \%$ for boys and girls and related to alcohol was $32.6 \%$ for both groups. Based on the study conclude the majority of respondents has inadequate knowledge regarding substance abuse. ${ }^{15}$

The study findings showed that a maximum $(80 \%)$ of the students had a good level of knowledge and (20\%) had an excellent level of knowledge regarding substances abuse. Thus, it was evident that the majority of students had gained a good and excellent level of knowledge regarding substances abuse. The mean score, median score and SD in the post-test was 22.58, 23 and 2.02, respectively.

This study was supported by Karnool and Raju"s quasiexperimental study on drug addiction among engineering students at Bangalore which showed that in post-test the overall mean knowledge score of the students is $76.63 \%$. In the pre-test, majority of students, had a mean knowledge score of $48.37 \%$. Thus it showed that structured teaching programs had a definite impact on raising the knowledge of students regarding drug addiction. ${ }^{29}$

The study revealed that Pre-test and post-test mean knowledge score was 12.78, 22.58 Respectively. The calculated „,t value was 19.2 which was significant at the $\mathrm{p}>0.05$ level while the tabled value on this level of significance was found at 1.645 . Hence null hypothesis was rejected and the research hypothesis was accepted i.e. the post-test knowledge score regarding substances abuse was significantly higher than the pre-test knowledge score. It can be safely assumed that STP had a definite impact on raising the knowledge of students on substance abuse.

This study was supported by Prathima Moorthy, N, Manjunatha's a pre-experimental study on knowledge about opioids and cocaine abuse among college students in Bangalore. Which show that the calculated $\mathrm{t}$ - value was $\mathrm{t}=$ 37.74 and was greater than the tabulated value at a $0.05 \%$ level of significance. The overall findings of the study showed that this structured teaching program is very effective in improving the knowledge of college students on opioids and cocaine. ${ }^{31}$

The current study findings showed that there is a significant association between the religion of students and pre-test. The chi-square value of religion was found to be 11.87. while the table value at the 0.05 level of significance was 3.84. no other demographic variable had a significant association with the pre-test knowledge score. 
The post-test there was found a significant association between the educational grade and post-test knowledge score. The chi-square value of educational grade was found to be 13.03 in post-test. Where the tabulated value at the 0.05 level of significance was 3.84 the study did not show any other significant association between demographic variable and post-test knowledge score.

This study was supported by Sreevani R's a quasiexperimental study on adverse effects of tobacco smoking among adolescent students in Tamaka dist. Kolar that there was no relationship between variables and knowledge of adolescence but there was the relationship between education and knowledge of adolescence regarding the adverse effect of tobacco and smoking. Based on findings the investigator concluded that PTP has improved the knowledge of adolescence regarding the adverse effect of tobacco and smoking 32.

\section{Conclusion}

The following conclusions were drawn based on the findings of the study. The majority of students had inadequate knowledge regarding substances abuse in the pre-test. Age of the boys, Education and Occupation of the parents, type of family and income of a family, Source of information regarding substances abuse had no impact on knowledge regarding substance abuse. A structured teaching program had a definite impact on students' knowledge regarding substances abuse. In the posttest majority of students had adequate knowledge regarding substances abuse.

\section{ReCOMmEndations}

A formal education program must be conducted in all senior secondary schools regarding substances abuse. The study can be replicated on a large sample; thereby findings can be generalized to a large population. A concentrated effort should be made to increase the awareness among the boys of senior secondary school students of their responsibilities in today's society. Substances abuse assessment (SAA) for adolescence and young adults could be held on a regular basis.

\section{REFERENCES}

1. Luciano M, Sampogna G. Vecchio V D, Pigani L, Palumbo C. Use of coercive measures in mental health practice and its impact on outcome. A critical review. Taylor \& Francis journals. 2014;14:131-141, Available from: https://doi.org/10.1586/1473717 5.2014 .874286

2. Lalitha K. Mental health and psychiatric nursing an Indian perspective. 1st edition. Lakshmidevinagar Bangalore: VMG book house; 2011;390-391.

3. Dari V Raj. Psychosocial problem among adolescent boys. [Internet] Jun 2009 [cited 2013 jan. 14] Available from: www. rguhs.ac.in/cdc/ online/cdc/uploads/ 05_N043_4120.doc

4. Sabiha J. Prevalence of drug and alcohol use among engineering college students. [Internet] April 2001. [cited 2013 Jan. 15] Available from: www.rguhs.ac.in/

5. Sinha D.N, Reddy S.K, Rahman K, Warren c w. Linking Global Youth tobacco survey Data to the W.H.O. Frame work convention on tobacco control: The case for India J Public Health. 2006; 40: 64-75 available from: http://ncbi.nlm.Nih. Gov/pubmed/.

6. Murthi P, Manjunatha N, Subodh B.N, Chand P. K. Substance use and addiction research in India. Indian journal of psychiatry.2010:52;189-199 available from: doi. org/10.4103\%2F0019-5545.69232

7. Chavan B S, Arun P, Bhargava R, Singh G P. Prevalence of alcohol and drug dependence in rural and slum population of Chandigarh: A community survey. Indian Journal of Psychiatry.2007;49(1): 44-48. Available from: doi.org/10.4103/0019-5545.31517

8. Emily C Feinstein, Linda Richter, Susan E Foster. Addressing the Critical Health Problem of Adolescent Substance Use Through Health Care, Research, and Public Policy. Journal of adolescent health. 2012(50) :431-436. Available from: doi.org/10.1016/j. jadohealth.2011.12.033

9. Thrappil D. S. Article Thrappil D. S. Article on assess the knowledge on substances abuse [internet] Jun 2005. [ Cited 2013 Feb 1] Available from: http://52.172.27.147:8080/jspui/ bitstream/123456789/4234/1/Tharappil\%20Sister\%20Deepthi. pdf

10. Ambekar A, Singh R. R. Problem with multifaceted drugs in the states [internet]. 2012 [cited on 2013 march 12] (32), 44-55. Available from: http://www.unodc.org

11. Sonn R.A. Substances abuse is one of the health hazards. [internet] Nov. 2009. [cited 2013 Feb. 4] Available from:www. sacpo.co.za/downloads/.../Substance

12. \%20Abuse. File Format: PDF.

13. Sinha DN, Reddy KS, Rahman K, Warren CW, Jones NR, Asma S. Linking Global Youth Tobacco Survey (GYTS) data to the WHO framework convention on tobacco control: the case for India. Indian J Public Health. 2006 Apr-Jun;50(2):76-89. PMID: 17191409.

14. Malik A.A, Nawaz S, Adeel Ali Tahir. Knowledge and awareness of harmful effect of substance abuse among users [internet]. Journal of the Pakistan medical association.2012;62(4):412. Available from: http://www.jpma.org.pk/full_article_text. php?article_id $=3375$

15. Kim S. Tobacco Use Insights [internet]. Dec. 2010 [cited 2014 Jan. 12]. Available from: http://www.la-press.com/smokingprevalence-and-the-association-between- smoking-andsociodemogr-article-a3275.

16. Mohaasa I.P. The study found that substances abused by the participants [Internet]. Feb. 2010 [cited 2014 Jan 14]. Available from: www.uir.unisa.ac.za/ bitstream/handle/10500/.../ dissertation formed inpdf

17. Aurore B, Teigna A, B, Genero C, Yola M. Drug Utilization Studies In Latin America: A Scoping Review And Survey Of Ethical Requirements. Elsevier.2018;17:189-193. Available From: https://doi.org/10.1016/j.vhri.2018.09.003

18. Sharma Priyanka, Tyagi Ankita. A study on Adolescent Drug Abuse in India: American International Journal of Research in Humanities, Arts and Social Sciences [internet]. : ISSN (Online): 2328-3696. 2016;16:244; Available from: http://iasir. net/AIJRHASSpapers/AIJRHASS16-244.pdf

19. Nebhinani N, Nebhinani M, Misra A.K, Grewal S. SubstanceRelated Knowledge and Attitude in School and College Students. German journal of psychiatry.2013;16(1):15-19 Available from: https://www.researchgate.net/publication/286179142_Substancerelated_knowledge_and_attitude_in_school_and_college_ students

20. Geramin N, Akhavan S, Gharaat L. Determinants of drug abuse in high school students and their knowledge and attitude 
[internet]. March 2012 [cited on 2014 Jan. 28]. Available from: http/www.jpma.org.pk. supliment40.

21. Erdogan ON, Erdogan MS, Kaya S, Ulus T. Knowledge, attitudes, and opinions of Turkish private school principals regarding substance abuse. J Pak Med Assoc. 2011 Oct;61(10):953-60. PMID: 22356025. Available from: https://pubmed.ncbi.nlm.nih. gov/22356025/

22. Haddad L, Shotar A, Umlauf M, Al-Zyoud S. Knowledge of substance abuse among high school students in Jordan. J Transcult Nurs. 2010 Apr;21(2):143-50. doi: 10.1177/1043659609357632. PMID: 20220034..

23. Masibo, R.M., Mndeme, E., \& Nsimba, S.E. An assessment of knowledge, attitudes and practices of psychoactive substance use among secondary school students in Dodoma Municipality , Tanzania. 2013. available from: https://www.semanticscholar. org/paper/An-assessment-of-knowledge-\%2C-attitudes-and-ofuse-\%2C-Masibo Mndeme/74bcee747f060de831fd8232bfa3fff2 e6975cf4\#citing-paper

24. Kalra I. Bansal P. D. Sociodemographic profile and pattern of drug abuse among Patients Presenting to a De-addiction Centre in rural area of Punjab [internet]. Delhi psychiatric journal October 2012, [cited 2013 Feb. 10]. vol. 15 no: 2, 23-27. Available from: http://medind.nic.in/daa/t12/i2/daat12i2p327.pdf

25. Sharma R, Singh J. Drugs in athlete. Indian Public Health [serial online] 2008 Jun 5 [cited on 2013 march 6]. Available from: http://dopingjournal.org/content/8/1/ dopingj082010-01.html\# menu

26. Saxena V, Saxena Y, Kishore G, Kumar P. A study on substance abuse among school going male adolescents of Doiwala Block, District Dehradun. Indian J Public Health [serial online] 2010 [cited 2014 Jan 5];54:197-200. Available from: http://www.ijph. in/text.asp2010/54/4/197/77260

27. Akoijam BS, Jamir MN, Phesao E, Senjam GS. Inhalant use among schoolchildren in northeast India: a preliminary study.
Subst Abuse. 2013 Oct 30;7:185-90. doi: 10.4137/SART.S12750. PMID: 24250225; PMCID: PMC3825564.

28. Gajalakshmi V, Kanimozhi CV. A Survey of 24,000 Students Aged 13-15 Years in India: Global Youth Tobacco Survey 2006 and 2009. Tobacco Use Insights.sage journals. January 2010. 3(9512):23-31. Available from: doi:10.1177/1179173X1000300001

29. Adepoju E.G, Olowookere S.A, Adeleke N.A, Afolabi O.T,Olajide F.O, Aluko O.O. A Population Based Study on the Prevalence of Cigarette Smoking [internet]. Feb. 6, 2013 [cited on 2014 march 12]. Available from: http://www.la- press. com/a-population-based-study-on-the-prevalence-of-cigarettesmoking-and- sm-article-a3518

30. Raju K. to assess the effectiveness of structured teaching programme (STP) on knowledge of engineering college students regarding drug addiction [internet]. Jun 2011 [cited on 2014 march 8]. Available from: http://52.172.27.147:8080/jspui/ bitstream/123456789/8981/3/Raju\%20Karnool.pdf

31. Kala K. A study was conducted to assess effectiveness of STP [internet]. 2007 [cited on 2014 march 13]. Available from: www.mptnai.org/.../ EFFECTIVENESS\%20OF\%20 STRUCTURED\%20T.

32. Murthy P, Manjunatha N. Department of Psychiatry deaddiction center [internet]. march28, 2011 [cited on 2013 march 8] IP:210.212.203.211. Available from: http://www. indianjpsychiatry.org/

33. Sreevani R. Effectiveness of planned teaching programme regarding adverse effects of tobacco smoking on knowledge gain of Xth standard students in a selected school of Kolar district. International conference: Indian journal of psychiatric nurses. Feb 2005;46.

34. Borghi J, Guinness L, Ouedraogo J, Curtis V. Is hygiene promotion cost-effective? A case study in Burkina Faso. Trop Med Int Health. 2002 Nov;7(11):960-9. Available from: doi: 10.1046/j.1365-3156.2002.00954.x. PMID: 12390603. 